\title{
Levels of MUC1 in tumours and serum of patients with different sub-types of squamous cell carcinoma of the head and neck
}

\author{
LINDA BOLDRUP $^{1}$, PHILIP COATES ${ }^{2}$, XIAOLIAN GU $^{1}$, LIXIAO WANG $^{1}$, \\ ROBIN FÅHRAEUS ${ }^{1-3}$, TORBEN WILMS $^{4}$, NICOLA SGARAMELLA ${ }^{1}$, \\ JONATHAN BAUMGARTH ${ }^{4}$, LENA NORBERG-SPAAK ${ }^{4}$ and KARIN NYLANDER ${ }^{1}$
}

\author{
${ }^{1}$ Department of Medical Biosciences, Umeå University, Umeå, Västerbotten 90187 , Sweden; ${ }^{2}$ Regional Centre for \\ Applied Molecular Oncology, Masaryk Memorial Cancer Institute, Brno, Southern Moravia 656 53, Czech Republic; \\ ${ }^{3}$ Institute of Molecular Genetics, University of Paris St. Louis Hospital, Paris, Île-de-France 750 10, France; \\ ${ }^{4}$ Department of Clinical Sciences, Umeå University Hospital, Umeå, Västerbotten 901 87, Sweden
}

Received December 6, 2019; Accepted May 14, 2020

DOI: $10.3892 / \mathrm{ol} .2020 .11746$

\begin{abstract}
Mucin 1 (MUC1) is a membrane-bound and secreted glycoprotein that has a protective role in surface epithelia. We recently demonstrated that MUC1 mRNA expression was upregulated in tumour-free tongue tissues adjacent to squamous cell carcinoma of the oral tongue (SCCOT) compared with that in the tumour tissues. The present study investigated MUC1 protein in SCCOT tissue and serum from patients with squamous cell carcinoma of the head and neck (SCCHN) at different sub-sites. The results from immunohistochemistry demonstrated that all SCCOT tissues expressed MUC1; however, the protein levels were not correlated with MUC1 mRNA levels in the same tumours. Furthermore, serum MUC1 level was lower in patients with SCCOT, tonsil SCC and gingival SCC compared with that in healthy subjects; however, the difference was only significant for patients with SCCOT $(\mathrm{P}=0.0421)$. No correlation was seen between MUC1 level in tumour tissues and MUCI level in serum from the same patients. The absence of correlation between MUC1 protein and mRNA levels in SCCOT tissues emphasized the importance of validating genomic data in clinical samples. Although significant MUC1 downregulation was observed in the serum of patients with SCCOT, there was a large variation within the groups, suggesting that MUC1 may not be used as a biomarker for these types of tumors.
\end{abstract}

\section{Introduction}

Squamous cell carcinoma of the head and neck (SCCHN) is a heterogeneous group of malignancies that includes tumours

Correspondence to: Dr Linda Boldrup, Department of Medical Biosciences, Umeå University, Building 6M Analysvägen 9, Umeå, Västerbotten 901 87, Sweden

E-mail: linda.boldrup@umu.se

Key words: mucin 1, squamous cell carcinomas of the oral tongue, blood markers, prognosis, microarray, validation from different locations within the head and neck area. More than 650,000 new cases are diagnosed every year worldwide and 330,000 death are caused by SCCHN (1) The most important sites in terms of number of cases are the oral cavity, oropharynx and larynx. The most well known risk factors are smoking and alcohol abuse (2), and for some sub-locations also HPV virus (3). From a functional and aesthetic aspect, SCCHN is a devastating disease with a low 5-year survival rate (4), mainly due to late detection and a high recurrence rate $(5,6)$. Numerous studies have therefore focused on finding reliable markers for diagnostic and prognostic use (7-10).

In a recent RNA profiling analysis of tumour and clinically normal tongue tissues from patients with squamous cell carcinoma of the oral tongue (SCCOT), the tongue being the most prevalent subsite of SCCHN, several genes were reported to be dysregulated in normal tongue tissues compared with those in tumour tissues, which was also the case in tongue samples from healthy individuals (11). These findings indicated that these genes may serve a crucial role in tumour induction and may therefore act as potential biomarkers of early neoplastic changes. One of the top 10 upregulated genes in tumour-free tissues was mucin 1 (MUC1), which encodes a membrane bound and secreted member of the mucin family known to have a protective role in epithelial surfaces (12). MUC1 also plays an essential role in maintaining cell homeostasis, promotes cell survival and participates in cell signal transduction $(13,14)$.

The soluble form of MUC1, which is often referred to as CA15-3, is generated by cleavage of the extracellular part of MUC1 from the cell surface by certain enzymes, including disintegrin and metalloproteases $(15,16)$. Elevated MUC1 serum level is associated with shorter disease-free survival and overall survival time in patients with breast cancer (17). Since MUC1 is one of the most highly upregulated genes in tumour-free tongue tissues (7), it could be used as a potential marker of so-called 'field changes' in SCCOT. These changes could be due to pre-neoplastic genetic events or be indicative of environmental alterations predisposing to tumour formation $(18,19)$. These field changes, including MUC1, could therefore represent biomarkers of early disease. 
In order to investigate this further, the present study compared MUC1 protein levels to previous MUC1 mRNA levels in FFPE tumour material from the same patients analysed for MUC1 mRNA, and evaluated MUC1 level in the serum from patients with SCCHN of different subsites.

\section{Materials and methods}

Patient samples. Paraffin-embedded tissues from 25 SCCOT tumours were used for immunohistochemistry analysis, performed by the accredited lab in clinical pathology at Umeå University, Sweden. Positive controls were biopsies of breast skin from breast reduction surgery and informed consent from the patients was obtained at the time of surgery. Only primary cases of SCC from the mobile tongue, with full access to clinicopathological data were included. In addition, 11 of these patients were also included in the blood analysis (Table I). All patients provided informed consent at Umeå University Hospital and the study was approved by the local Ethics Committee (approval no. Dnr 08-003M). All samples were collected at Umeå University Hospital between February 2003 and August 2017 during a diagnostic biopsy procedure. All tumours are classified with the Tumor-Node-Metastasis (TNM) system according to the 7th edition (20).

Blood collection. Blood was collected from healthy 28 controls, 26 patients with SCCOT, 20 patients with gingival SCC and 13 patients with tonsil SCC. Blood samples were collected in connection with diagnostic examination/surgical procedure. The inclusion criteria were the same as stated for the aforementioned patient samples. The clinicopathological information for all patients are presented in Table I; however, the data for the control cohort of 28 healthy volunteers (median age of 50.5 consisting of 17 females and 11 males) were not available. Peripheral blood $(3 \mathrm{ml})$ was collected using standardized venipuncture procedures into vacutainers (SST ${ }^{\mathrm{TM}} \mathrm{II}$; cat. no. 368498; BD Biosciences) containing a serum separator, an acrylic-based gel that forms a barrier between the clot and the serum after centrifugation, but not an anticoagulant. Tubes were left standing for at least $30 \mathrm{~min}$ at room temperature after blood collection and centrifuged at $1,300 \mathrm{x}$ for $10 \mathrm{~min}$ at room temperature. The serum layer was subsequently collected and stored at $-80^{\circ} \mathrm{C}$ until further use. All controls and patients provided informed consent at Umeå University Hospital and the study was approved by the local Ethics Committee (approval no. Dnr 08-003M).

Immunohistochemistry. Immunohistochemistry was performed in an accredited pathology laboratory at Umeå University Hospital, with positive controls (normal skin from breast taken at reduction surgery) included in each batch. In brief, paraffin-embedded SCCOT tissues were sectioned into 5- $\mu \mathrm{m}$ thick sections. Sections were pre-treated in EDTA-antigen retrieval solution (Cell Conditioning Solution, CCl; Ventana Medical Systems, Inc.) for $64 \mathrm{~min}$ and then incubated with the primary antibody against $\mathrm{MUC1}$ in $36^{\circ} \mathrm{C}$ (ready to use, Roche Diagnostics; cat. no. 790-4574 H2) for $32 \mathrm{~min}$. Detection was performed with an ULTRAVIEW kit (cat. no. 760-500; Ventana Medical Systems, Inc.) following the manufacturers' protocols. MUC1 staining was evaluated by determining a quickscore (QS) system (21) using the light microscope, Olympus BX51 with a magnification of $3.2 \mathrm{X}$ and
20X. The percentage of MUC1-expressing tumour cells ranged from 1 to 6 as follows: $0-4 \%$, score $1 ; 5-19 \%$, score $2 ; 20-39 \%$, score $3 ; 40-59 \%$, score $4 ; 60-79 \%$, score 5 ; and $80-100 \%$, score 6 . The staining intensity was classified as follows: Negative, score 0 ; weak, score 1; intermediate, score 2; or strong, score 3. The QS was obtained by multiplying the expression and intensity scores, which provided a range from 0 to 18 . QS between 1-5 are interpreted as low expression and QS between 6-12 medium expression. The scoring was performed blinded by two individuals, and in cases of disagreement, slides were re-evaluated and discussed until a consensus score was given. Differentiation of tumours were classified as poor, poor-moderate, moderate, moderate-high and high.

MUCl blood detection. Serum samples were analysed using the R-PLEX Human CA15.3 Antibody Set (Meso Scale Diagnostics). The R-plex singleplex assay protocol was followed. Briefly, a 96-well plate was coated with $200 \mu$ l biotinylated capture antibody (Meso Scale Diagnostics) in coating diluent consisting of $0.5 \%$ BSA (Roche Diagnostics) in PBS for $1 \mathrm{~h}$ at room temperature with agitation, and subsequently washed with PBS containing $0.05 \%$ Tween. Eight calibrator standards $(25 \mu \mathrm{l})$ of a 4-fold serial dilution were prepared from the Meso Scale Diagnostics supplied calibrator in triplicate. Serum samples were diluted 5-fold (total volume $25 \mu \mathrm{l}$ ). Plates were incubated for $1 \mathrm{~h}$, with agitation, at room temperature. After washing with PBS with $0.05 \%$ Tween, $50 \mu \mathrm{l}$ detection antibody solution was added to each well and incubated for $1 \mathrm{~h}$ at room temperature under shaking. The plate was washed with PBS with $0.05 \%$ Tween before adding $150 \mu \mathrm{l}$ MSD GOLD read buffer (from the aforementioned kit) to each well. The plate was immediately analysed using an Meso scale Diagnostics instrument, MESO QuickPlex SQ120 (Meso Scale Diagnostics). MUC1 concentration $(\mathrm{U} / \mathrm{ml})$ was calculated from the calibrator standard curve.

Statistical methods. Data were analyzed using SPSS version 26 (IBM Corp.). For comparison of MUC1 serum levels in SCCHN and controls, the non-parametric Mann-Whitney U test was used, and for comparison between controls and multiple sub-groups, Kruskal-Wallis test with Dunn's post hoc test was used. To investigate the correlation between MUC1 protein levels in tissue and MUC1 RNA expression in tissue, and between MUC1 protein levels in serum and tissue, Spearman correlation coefficient ( $\rho$ ) was used. Furthermore, patients were divided into two groups depending on the QS score as follows: MUC1 low, represented by a QS of 1 to 5; and MUC1 medium, represented by a QS of 6 to 12 . The associations between clinicopathological characteristics of patients and the MUC1 serum levels were determined by using the $\chi^{2}$ test. For parameters where $\geq 20 \%$ of the cells had an expected count of $<5$, Fisher's exact test was used instead. For associations between categorized clinicopathological variables and circulating MUC1, Mann-Whitney U or Kruskal-Wallis test were used. One-way ANCOVA was used to correct for age in the comparison of gender. $\mathrm{P}<0.05$ was considered to indicate a statistically significant difference.

\section{Results}

MUC1 protein expression was evaluated in primary SCCOT tissues. The results demonstrated that MUC1 was primarily 


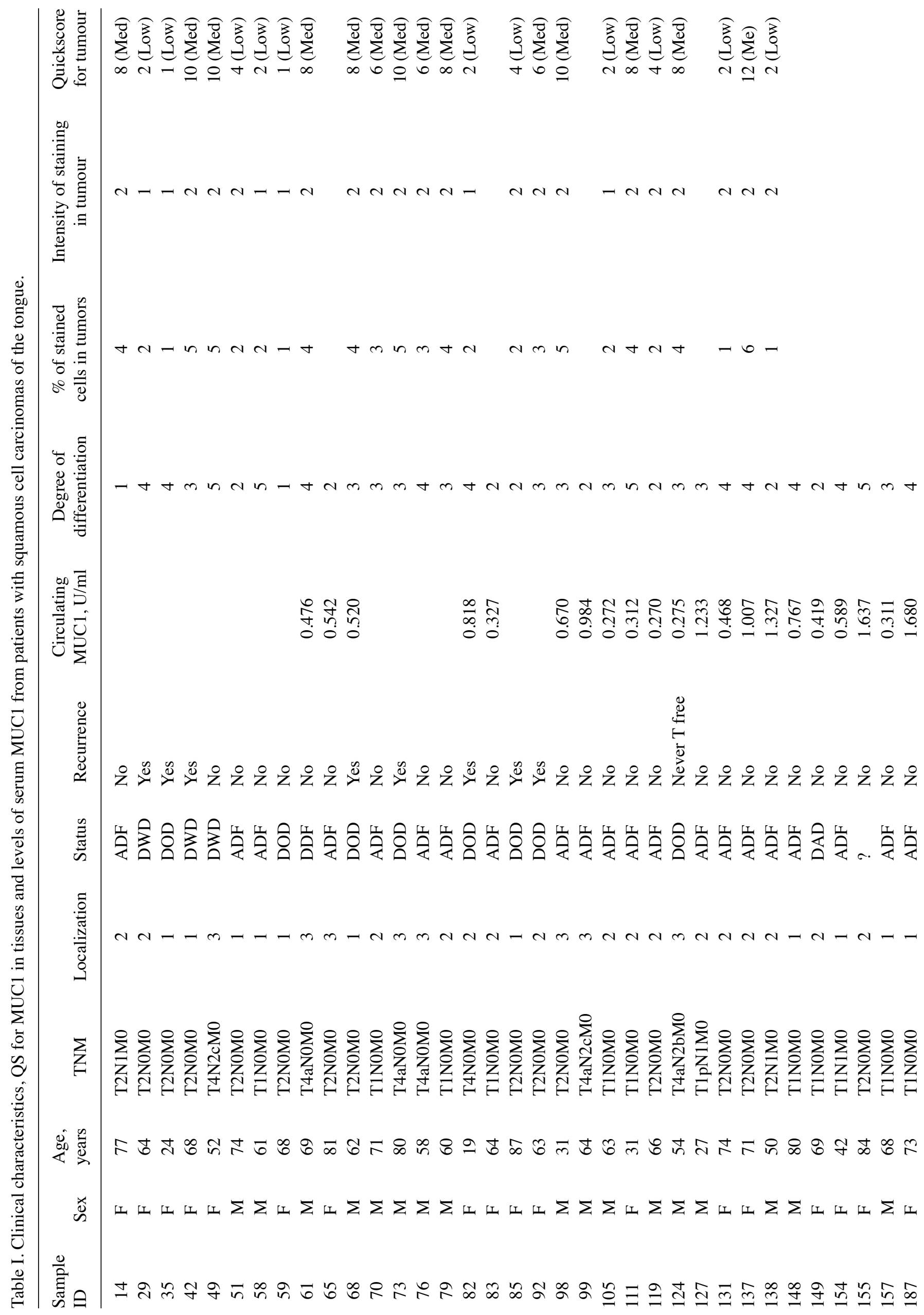




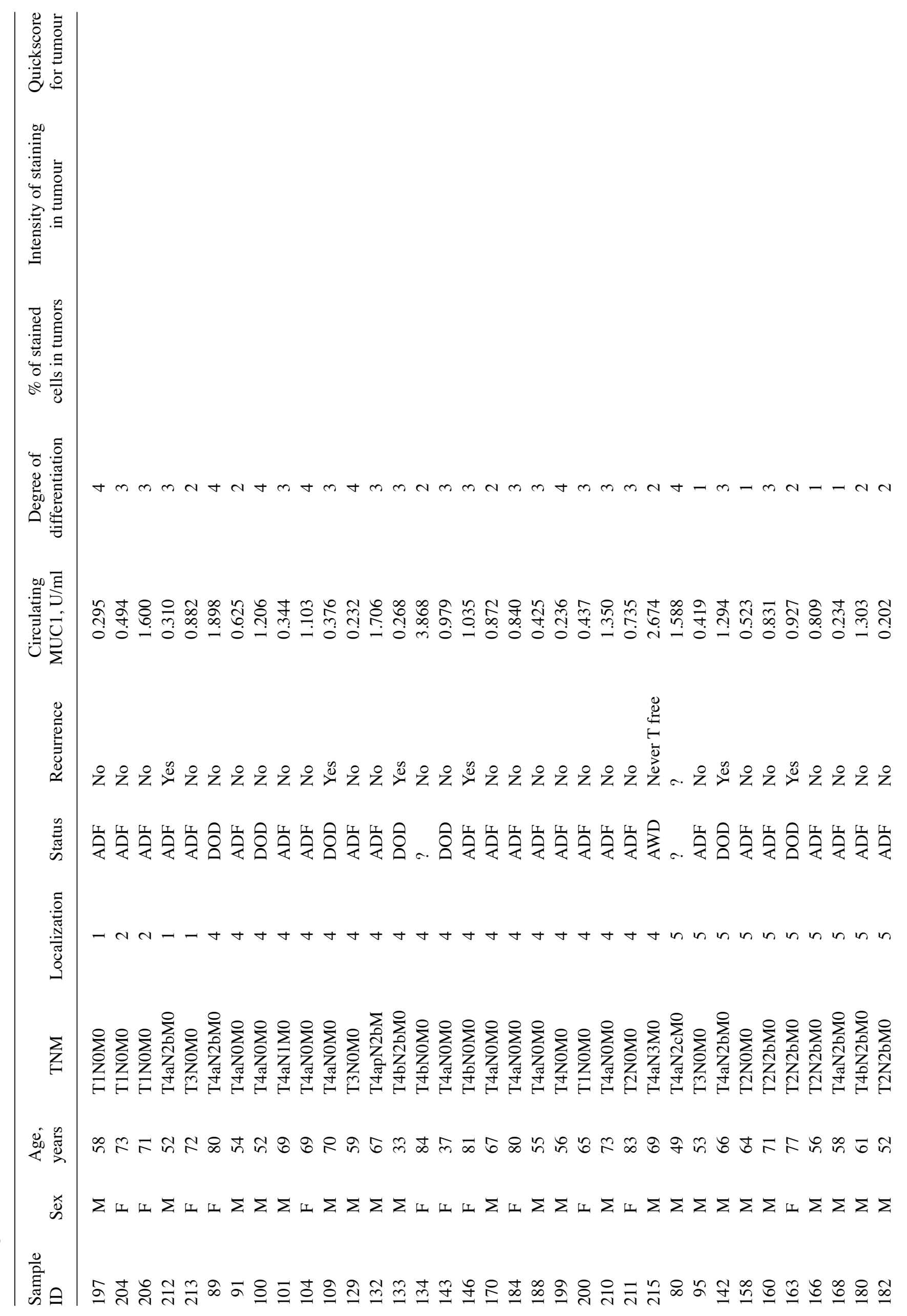


located in the plasma membrane; however, MUC1 was also located in the cytoplasm of some samples (Fig. 1). All 25 tumours analysed expressed MUC1, with 11 tumours presenting low levels (QS 1-5) and 14 presenting medium levels (QS 6-12). No tumour had a QS >12 (Table I). No correlation between QS and our previously measured mRNA levels (11) was observed ( $\rho=0.11 ; P=0.599$ ) (data not shown).

The levels of circulating MUC1 were measured in serum from patients with SCCOT and controls. The results demonstrated that MUC1 serum level was significantly downregulated in patients with SCCOT compared with that in controls $(\mathrm{P}=0.0421$; Fig. 2 and Table II). Serum from patients with gingival $(n=20)$ and tonsil $(n=13)$ SCC were also analysed and the results demonstrated that MUC1 serum level was downregulated in both gingival $(\mathrm{P}=0.8284)$ and tonsillar $(\mathrm{P}=0.0659)$ tumours compared with the controls, although this difference was not significant (Fig. 2 and Table II). No correlation was observed between MUC1 expression in tumour tissues (QS values) and circulating MUC1 levels in the 11 patients with both tissue and serum ( $\rho=0.157, P=0.644$ ) (data not shown).

To investigate the association between the clinicopathological characteristics and MUC1 protein expression in tissue, patients with low (QS of 1-5) and medium (QS of 6-12) levels were compared. Of all characteristics tested, the only significant association was seen for the degree of differentiation, where half of the tumours $(5 / 10 ; 50 \%)$ with moderate-high or high differentiation showed medium expression, whereas only 1 out of 6 (17\%) of the tumours with poor-moderate or poor differentiation showed medium expression (Table III). In addition, comparison between the same clinicopathological characteristics and MUC1 serum level was performed. By comparing the age groups using Kruskal Wallis, it was demonstrated that MUC1 serum levels were different in the different age groups; however, using Spearman's correlation analysis the MUC1 serum levels were not correlated $\left(r_{s}=0.257\right)$. Women had a significantly higher age (mean, 67.3 years) compared with the men (mean 58.3 years), and a one-way ANCOVA was used to correct for age when comparing the sexes, and the results showed no association between men and women (Table IV).

\section{Discussion}

In agreement with previous immunohistochemical studies on SCCHN and oral squamous cell carcinoma (22-24), the present study reported the presence of MUC1 in all SCCOT tissues analysed; however, MUC1 expression in the tissues was not correlated with previously measured mRNA levels in the same tumour tissue specimens (11). This inconsistency suggested that MUC1 protein level is regulated after mRNA synthesis, via post-transcriptional, translational, post-translational and protein degradation pathways. It has been reported that only $40 \%$ of protein concentration variation can be explained by corresponding changes in mRNA levels $(25,26)$. The differences in MUC1 protein and mRNA levels in tissues must be further validated to determine the value of these levels as diagnostic and prognostic markers.

Regarding the clinicopathological characteristics of patients with SCCOT, the degree of differentiation was the only characteristic associated with MUC1 serum level. Here, 
A

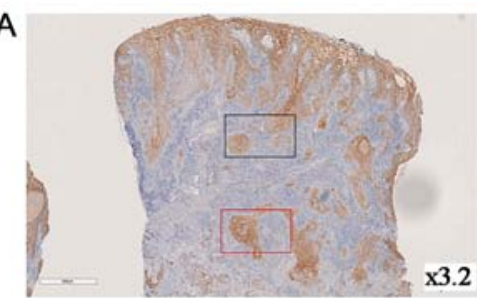

B

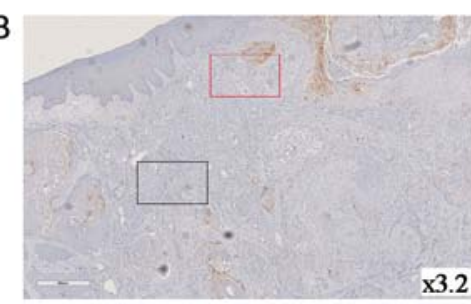

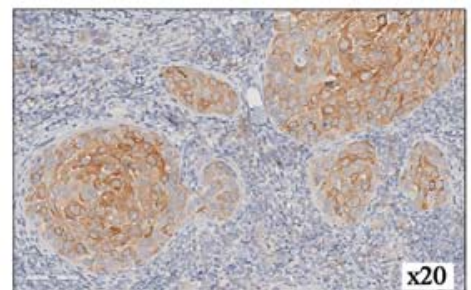
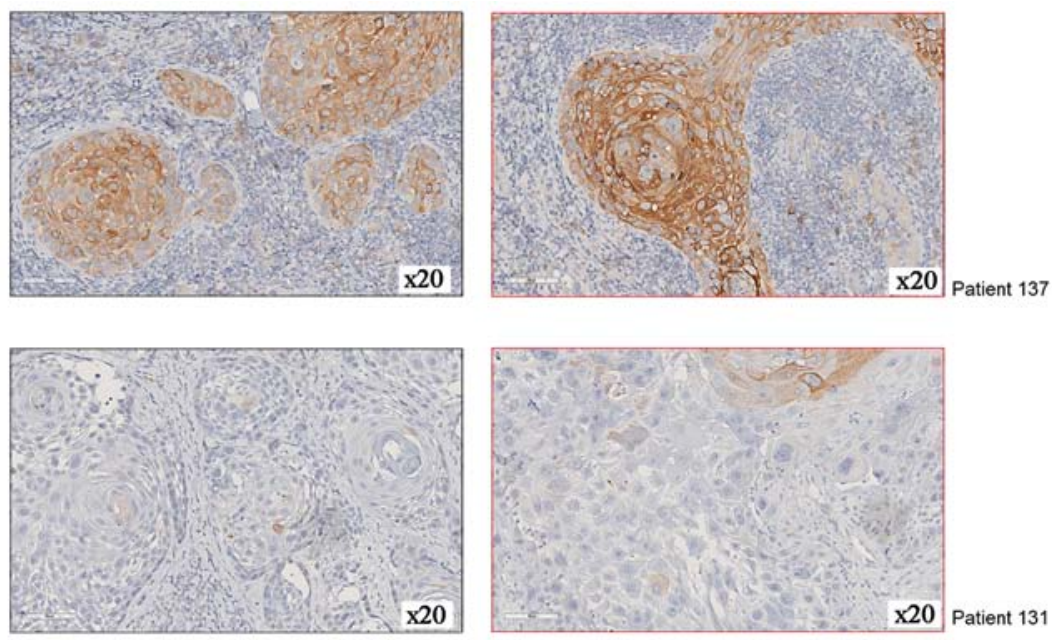

Figure 1. Representative images of tissues following MUC1 immunohistochemistry: (A) Patient 137 with medium levels of MUC1 and (B) patient 131 with low levels of MUC1. MUC1, mucin 1.

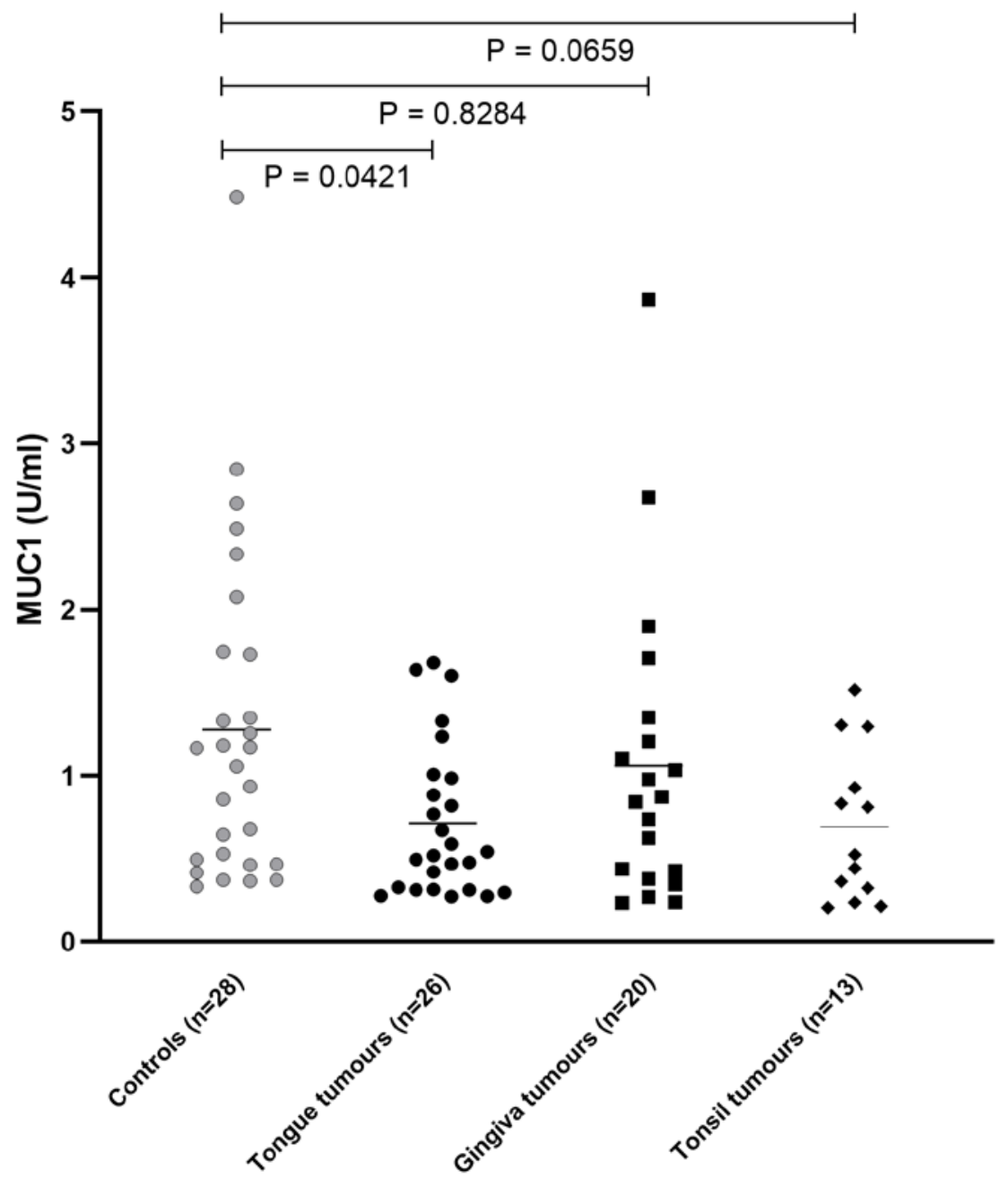

Figure 2. Detection of circulating MUC1 in serum of patients with squamous cell carcinomas of the oral tongue. Samples were collected from patients with SCCOT tongue SCC $(n=26)$, gingival SCC $(n=20)$ and tonsil SCC $(n=13)$, and were compared with the control group ( $n=28)$. SCC, squamous cell carcinoma; SCCOT, squamous cell carcinoma of the oral tongue.

only 1 of the 6 tumours with poor-moderate or poor differentiation showed medium MUC1 expression, whereas 50\% of the high-moderate or high differentiated tumours did. This result could mirror the homeostatic function exerted by MUC1 in epithelia with levels kept higher in highly differentiated tumours more resembling the normal epithelium. 
Table II. Levels of circulating MUC1 in patients with SCCHN.

\begin{tabular}{lccccr}
\hline & & \multicolumn{2}{c}{ MUC1 serum level, U/ml } & & \\
\cline { 3 - 4 } Sample group & Number & Mean \pm SD & Median & Fold-change & P-value \\
\hline Total & 87 & $0.97 \pm 0.80$ & 0.77 & & \\
Controls & 28 & $1.28 \pm 0.98$ & 1.11 & & 0.05 \\
SCCHN & 59 & $0.83 \pm 0.66$ & 0.63 & 0.55 & $0.042^{\mathrm{b}}$ \\
Tongue & 26 & $0.71 \pm 0.45$ & 0.53 & 0.83 & $0.828^{\mathrm{b}}$ \\
Gingiva & 20 & $1.06 \pm 0.91$ & 0.86 & 0.76 & $0.066^{\mathrm{b}}$ \\
Tonsils & 13 & $0.97 \pm 0.80$ & 0.77 & & \\
\hline
\end{tabular}

${ }^{a}$ Mann-Whitney U; 'Kruskal-Wallis with Dunn's correction. SCCHN, squamous cell carcinoma of the head and neck; SD, standard deviation; MUC1, mucin 1.

Table III. Association between MUC1 protein in tissue and clinicopathological characteristics of patients with SCCOT.

\begin{tabular}{|c|c|c|c|c|}
\hline \multirow[b]{2}{*}{ Characteristic } & \multicolumn{4}{|c|}{ MUC1 levels in SCCOT tumours } \\
\hline & QS 1-5 (low), n & QS 6-12 (medium), $\mathrm{n}$ & Total, $\mathrm{n}$ & P-value \\
\hline Age at diagnosis, years & & & & $0.936^{\mathrm{a}}$ \\
\hline$<40$ & 2 & 2 & 4 & \\
\hline $41-65$ & 4 & 6 & 10 & \\
\hline$\geq 66$ & 5 & 6 & 11 & \\
\hline Sex & & & & $0.561^{\mathrm{a}}$ \\
\hline Female & 6 & 6 & 12 & \\
\hline Male & 5 & 8 & 13 & \\
\hline T Stage & & & & $0.180^{\mathrm{b}}$ \\
\hline $\mathrm{T} 1, \mathrm{~T} 2$ & 10 & 9 & 19 & \\
\hline $\mathrm{T} 3, \mathrm{~T} 4$ & 1 & 5 & 6 & \\
\hline Lymph node status & & & & $0.604^{\mathrm{b}}$ \\
\hline Negative & 10 & 11 & 21 & \\
\hline Positive & 1 & 3 & 4 & \\
\hline TNM stage & & & & $0.234^{\mathrm{b}}$ \\
\hline I, II & 9 & 8 & 17 & \\
\hline III, IV & 2 & 6 & 8 & \\
\hline Degree of differentiation & & & & $0.022^{\mathrm{b}}$ \\
\hline Poor & 2 & 6 & 8 & \\
\hline Poor-moderate & 1 & 1 & 2 & \\
\hline Moderate & 4 & 0 & 4 & \\
\hline Moderate-high & 4 & 3 & 7 & \\
\hline High & 1 & 2 & 3 & \\
\hline Recurrence & & & & $0.556^{\mathrm{b}}$ \\
\hline No & 7 & 9 & 16 & \\
\hline Yes & 4 & 4 & 8 & \\
\hline Overall survival & & & & $0.821^{\mathrm{a}}$ \\
\hline Yes & 6 & 7 & 13 & \\
\hline No & 5 & 7 & 12 & \\
\hline
\end{tabular}

One patient was never tumour free, therefore it cannot be determined if the patient developed recurrence or not. ${ }^{\mathrm{a}} \chi^{2}$ test; ${ }^{\mathrm{b}} \mathrm{Fisher}$ 's exact test. TNM, Tumor-Node-Metastasis; QS, quickscore; MUC1, mucin 1. Overall survival, alive at least 2 years after end of treatment. 
Table IV. Associations between circulating MUC1 levels and clinicopathological characteristics of patients with squamous cell carcinoma of the head and neck.

\begin{tabular}{|c|c|c|c|c|}
\hline Characteristic & $\mathrm{n}$ & Mean \pm SD & Median & P-value \\
\hline Age at diagnosis, years & & & & $0.004^{\mathrm{a}}$ \\
\hline$<40$ & 6 & $0.71 \pm 0.38$ & 0.74 & \\
\hline $41-65$ & 25 & $0.56 \pm 0.40$ & 0.42 & \\
\hline$\geq 66$ & 28 & $1.09 \pm 0.79$ & 0.88 & \\
\hline Sex & & & & $0.216^{\mathrm{b}}$ \\
\hline Female & 22 & $1.03 \pm 0.78$ & 0.86 & \\
\hline Male & 37 & $0.71 \pm 0.55$ & 0.48 & \\
\hline T stage & & & & $0.324^{\mathrm{c}}$ \\
\hline $\mathrm{T} 1, \mathrm{~T} 2$ & 29 & $0.69 \pm 0.44$ & 0.52 & \\
\hline $\mathrm{T} 3, \mathrm{~T} 4$ & 30 & $0.96 \pm 0.81$ & 0.86 & \\
\hline Lymph node metastasis & & & & $0.778^{\mathrm{c}}$ \\
\hline Negative & 37 & $0.78 \pm 0.66$ & 0.52 & \\
\hline Positive & 22 & $0.86 \pm 0.67$ & 0.86 & \\
\hline TNM stage & & & & $0.313^{\mathrm{c}}$ \\
\hline I, II & 20 & $0.66 \pm 0.46$ & 0.51 & \\
\hline III, IV & 39 & $0.91 \pm 0.73$ & 0.83 & \\
\hline Degree of differentiation & & & & $0.847^{\mathrm{a}}$ \\
\hline Poor & 4 & $0.50 \pm 0.24$ & 0.47 & \\
\hline Poor-moderate & 16 & $0.99 \pm 0.98$ & 0.75 & \\
\hline Moderate & 22 & $0.74 \pm 0.46$ & 0.60 & \\
\hline Moderate-high & 15 & $0.84 \pm 0.56$ & 0,77 & \\
\hline High & 2 & $0.98 \pm 0.94$ & 0.98 & \\
\hline Recurrence & & & & $0.806^{\mathrm{c}}$ \\
\hline No & 47 & $0.82 \pm 0.65$ & 0.63 & \\
\hline Yes & 8 & $0.69 \pm 0.38$ & 0.67 & \\
\hline Overall survival & & & & $0.321^{\mathrm{c}}$ \\
\hline Yes & 43 & $0.74 \pm 0.52$ & 0.59 & \\
\hline No & 16 & $1.05 \pm 0.92$ & 0.87 & \\
\hline
\end{tabular}

Recurrence status is missing for the patients that are never tumour free. ${ }^{\mathrm{a} K r u s k a l-W a l l i s ~ w i t h ~ D u n n ' s ~ p o s t ~ h o c ~ t e s t ; ~}{ }^{\mathrm{b}}$ One-way ANCOVA corrected for age; 'Mann-Whitney U. SCCOT, squamous cell carcinomas of the oral tongue.

The soluble MUC1 level in the circulation was also analysed, since it has been reported as a biomarker for cancer staging and relapse monitoring in patients with breast and gastrointestinal tumours $(27,28)$. Patients with breast cancer and presenting with high levels of circulating MUC1 have a significantly shorter overall survival time compared with patients with low levels (29), and levels of soluble MUC1 have been used for monitoring the therapeutic effect in patients with metastatic disease (30). In the present study, a significant downregulation of MUC1 in serum from patients with tongue SCC was observed compared with that in serum from control patients, but not from patients with gingival and tonsil SCC. This was another example of subsite tissue-specific alteration, which has been previously reported within the whole head and neck region (31-33). In addition, none of the patients in the present study possessed high levels of MUC1 (CA15-3) that are used clinically in breast cancer with cut-off values of $20-30 \mathrm{U} / \mathrm{ml}$ or higher $(17,18,20), 4 \mathrm{U} / \mathrm{ml}$ was the highest level measured in the patients from the present study.
These data in SCCHN, including SCCOT, were therefore similar to those in other types of cancer in which circulating MUC1 levels only had prognostic value in a minority of patients with large and/or widespread disease at the time of diagnosis (30). The result from immunohistochemistry showing that SCCOT tissues may be strongly positive for MUC1 but not correlated with serum levels may also be due to variable levels of MUC1 shedding, depending on expression and activity of sheddases and their inhibitors $(15,16)$.

The present study demonstrated that MUC1 circulating level was associated with sex, and women presented with significantly more tumours with high MUC1 expression (68\%) than men (38\%). However, the mean age of women was higher (67.3 years) than men (58.3 years), which is a factor that could affect normal processes within the epithelium.

There are many different models for studying cancer, including primary cultures of cancer cells $(34,35)$; a cell line model can never completely mimic what happens in an entire 
organism. For future studies on the function of MUC1 in cancer cells, a cancer cell line model can be useful in order to assess MUC1 interactions with other molecules. A correlation between MUC1 expression with E-cadherin and $\beta$-catenin expression has been previously reported in pancreatic and breast cancer cell lines where decreased expression of MUC1 leads to increased expression of E-cadherin and $\beta$-catenin and thus, to altered cell migration (36). A previous study on colorectal cancer also demonstrated that $\mathrm{MUC1}$ is involved in the tumoral process when p53 is overexpressed (37).

In conclusion, the present study demonstrated that there was no correlation between MUC1 mRNA expression and MUC1 protein expression in SCCOT tissues, suggesting the importance of validating genomic data in clinical samples. Furthermore, the large variations in serum levels of MUC1 observed within the subgroups of SCCHN patients indicated that MUC1 may not be used in clinical practice as a serum biomarker for these types of tumours. Although the number of samples studied was limited, all samples were collected according to strict inclusion criteria and at the same hospital, and were handled by two experienced researchers, making the groups as homogenous as possible.

\section{Acknowledgements}

Not applicable.

\section{Funding}

This work was supported by grants from the Cancer Research Foundation in Northern Sweden, Lion's Cancer Research Foundation, Umeå University, the Swedish Cancer Society (contract number 18 0542) and Region Västerbotten in Sweden. Grants by Ministry of Health, Czech Republic - conceptual development of research organization (MMCI, 00209805).

\section{Availability of data and materials}

All data generated or analyzed during the present study are included in this published article.

\section{Authors' contributions}

LB designed the study, performed the experiments and analyzed data. KN designed and supervised the project. RF assisted in designing the study. $\mathrm{LB}, \mathrm{RF}, \mathrm{KN}$ and $\mathrm{PC}$ wrote the manuscript. PC analyzed data. XG and LW analyzed data and revised the manuscript. TW, NS, JB and LNS provided medical materials, clinical data and assisted in the analysis of clinical data. All authors read and approved the final manuscript.

\section{Ethics approval and consent to participate}

All patients provided informed consent and the study was approved by the Local Ethics Committee at Umeå University Hospital, Sweden (approval no. Dnr 08-003M).

\section{Patient consent for publication}

Not applicable.

\section{Competing interests}

The authors declare that they have no competing interests.

\section{References}

1. Bray F, Ferlay J, Soerjomataram I, Siegel RL, Torre LA and Jemal A: Global cancer statistics 2018: GLOBOCAN estimates of incidence and mortality worldwide for 36 cancers in 185 countries. CA Cancer J Clin 68: 394-424, 2018.

2. Lubin JH, Purdue M, Kelsey K, Zhang ZF, Winn D, Wei Q, Talamini R, Szeszenia-Dabrowska N, Sturgis EM, Smith E, et al: Total exposure and exposure rate effects for alcohol and smoking and risk of head and neck cancer: A pooled analysis of case-control studies. Am J Epidemiol 170: 937-947, 2009.

3. Mork J, Lie AK, Glattre E, Hallmans G, Jellum E, Koskela P, Møller B, Pukkala E, Schiller TJ, Youngman L, et al: Human papillomavirus infection as a risk factor for squamous-cell carcinoma of the head and neck. N Engl J Med 344: 1125-1131, 2001.

4. Siegel RL, Miller KD and Jemal A: Cancer statistics, 2015. CA Cancer J Clin 65: 5-29, 2015.

5. Agra IM, Carvalho AL, Pinto CA, Martins EP, Filho JG, Soares FA and Kowalski LP: Biological markers and prognosis in recurrent oral cancer after salvage surgery. Arch Otolaryngol Head Neck Surg 134: 743-749, 2008

6. Carvalho AL, Magrin J and Kowalski LP: Sites of recurrence in oral and oropharyngeal cancers according to the treatment approach. Oral Dis 9: 112-118, 2003.

7. Sgaramella N, Gu X, Boldrup L, Coates PJ, Fahraeus R, Califano L, Tartaro G, Colella G, Spaak LN, Strom A, et al: Searching for new targets and treatments in the battle against squamous cell carcinoma of the head and neck, with specific focus on tumours of the tongue. Curr Top Med Chem 18: 214-218, 2018.

8. Li G, Da M, Zhang W, Wu H, Ye J, Chen J, Ma L, Gu N, Wu Y and Song X: Alteration of serum lipid profile and its prognostic value in head and neck squamous cell carcinoma. J Oral Pathol Med 45: 167-172, 2016.

9. Schaaij-Visser TB, Brakenhoff RH, Leemans CR, Heck AJ and Slijper M: Protein biomarker discovery for head and neck cancer. J Proteomics 73: 1790-1803, 2010.

10. Hsiung DT, Marsit CJ, Houseman EA, Eddy K, Furniss CS, McClean MD and Kelsey KT: Global DNA methylation level in whole blood as a biomarker in head and neck squamous cell carcinoma. Cancer Epidemiol Biomarkers Prev 16: 108-114, 2007.

11. Boldrup L, Gu X, Coates PJ, Norberg-Spaak L, Fahraeus R, Laurell G, Wilms T and Nylander K: Gene expression changes in tumor free tongue tissue adjacent to tongue squamous cell carcinoma. Oncotarget 8: 19389-19402, 2017.

12. van Putten JPM and Strijbis K: Transmembrane mucins: Signaling receptors at the intersection of inflammation and cancer. J Innate Immun 9: 281-299, 2017.

13. Lau SK, Weiss LM and Chu PG: Differential expression of MUC1, MUC2, and MUC5AC in carcinomas of various sites: An immunohistochemical study. Am J Clin Pathol 122: 61-69, 2004.

14. Ahmad R, Rajabi H, Kosugi M, Joshi MD, Alam M, Vasir B, Kawano T, Kharbanda S and Kufe D: MUC1-C oncoprotein promotes STAT3 activation in an autoinductive regulatory loop. Sci Signal 4: ra9, 2011.

15. Carson DD: The cytoplasmic tail of MUC1: A very busy place. Sci Signal 1: pe 35, 2008.

16. Thathiah A and Carson DD: MT1-MMP mediates MUC1 shedding independent of TACE/ADAM17. Biochem J 382: 363-373, 2004.

17. LiX,Dai D, Chen B, Tang H,Xie X and Wei W: Clinicopathological and prognostic significance of cancer antigen 15-3 and carcinoembryonic antigen in breast cancer: A meta-analysis including 12,993 patients. Dis Markers 2018: 9863092, 2018.

18. Angadi PV, Savitha JK, Rao SS and Sivaranjini Y: Oral field cancerization: Current evidence and future perspectives. Oral Maxillofac Surg 16: 171-180, 2012.

19. Lochhead P, Chan AT, Nishihara R, Fuchs CS, Beck AH, Giovannucci E and Ogino S: Etiologic field effect: Reappraisal of the field effect concept in cancer predisposition and progression. Mod Pathol 28: 14-29, 2015.

20. Sobin LH, Gospodarowicz MK, Wittekind C (eds): TNM classification of malignant tumours. 7th Edition. Wiley-Blackwell, Chichester, West Sussex, 2009. 
21. Detre S, Saclani Jotti G and Dowsett M: A 'quickscore' method for immunohistochemical semiquantitation: Validation for oestrogen receptor in breast carcinomas. J Clin Pathol 48: 876-878, 1995

22. Croce CM and Calin GA: miRNAs, cancer, and stem cell division. Cell 122: 6-7, 2005.

23. Kumar MH, Sanjai K, Kumarswamy J, Keshavaiah R, Papaiah L and Divya S: Expression of MUC1 mucin in potentially malignant disorders, oral squamous cell carcinoma and normal oral mucosa: An immunohistochemical study. J Oral Maxillofac Pathol 20: 214-218, 2016.

24. Nitta T, Sugihara K, Tsuyama $S$ and Murata F: Immunohistochemical study of MUC1 mucin in premalignant oral lesions and oral squamous cell carcinoma: Association with disease progression, mode of invasion, and lymph node metastasis. Cancer 88: 245-254, 2000.

25. de Sousa Abreu R, Penalva LO, Marcotte EM and Vogel C: Global signatures of protein and mRNA expression levels. Mol Biosyst 5: 1512-1526, 2009.

26. Maier T, Guell $M$ and Serrano L: Correlation of mRNA and protein in complex biological samples. FEBS Lett 583: 3966-3973, 2009.

27. Safi F, Kohler I, Rottinger $\mathrm{E}$ and Beger $\mathrm{H}$ : The value of the tumor marker CA 15-3 in diagnosing and monitoring breast cancer. A comparative study with carcinoembryonic antigen. Cancer 68: 574-582, 1991.

28. Steinberg W: The clinical utility of the CA 19-9 tumor-associated antigen. Am J Gastroenterol 85: 350-355, 1990.

29. Duffy MJ, Duggan C, Keane R, Hill ASK, McDermott E, Crown J and O'Higgins N: High preoperative CA 15-3 concentrations predict adverse outcome in node-negative and node-positive breast cancer: Study of 600 patients with histologically confirmed breast cancer. Clin Chem 50: 559-563, 2004.
30. Duffy MJ, Evoy D and McDermott EW: CA 15-3: Uses and limitation as a biomarker for breast cancer. Clin Chim Acta 411: 1869-1874, 2010.

31. Boldrup L, Coates PJ, Laurell G and Nylander K: Differences in p63 expression in SCCHN tumours of different sub-sites within the oral cavity. Oral Oncol 47: 861-865, 2011.

32. Boldrup L, Coates PJ, Wahlgren M, Laurell G and Nylander K: Subsite-based alterations in miR-21, miR-125b, and miR-203 in squamous cell carcinoma of the oral cavity and correlation to important target proteins. J Carcinog 11: 18, 2012.

33. Ledgerwood LG, Kumar D, Eterovic AK, Wick J, Chen K, Zhao H, Tazi L, Manna P, Kerley S, Joshi R, et al: The degree of intratumor mutational heterogeneity varies by primary tumor sub-site. Oncotarget 7: 27185-27198, 2016.

34. De Vita A, Miserocchi G, Recine F, Mercatali L, Pieri F, Medri L, Bongiovanni A, Cavaliere D,Liverani C, Spadazzi C, et al: Activity of eribulin in a primary culture of well-differentiated/dedifferentiated adipocytic sarcoma. Molecules 21: 1662, 2016.

35. Oppel F, Shao S, Schurmann M, Goon P, Albers AE and Sudhoff H: An effective primary head and neck squamous cell carcinoma in vitro model. Cells 8: 555, 2019.

36. Yuan Z, Wong S, Borrelli A and Chung MA: Down-regulation of MUC1 in cancer cells inhibits cell migration by promoting E-cadherin/catenin complex formation. Biochem Biophys Res Commun 362: 740-746, 2007.

37. Tanimoto T, Tanaka S, Haruma K, Yoshihara M, Sumii K, Kajiyama G, Shimamoto F and Kohno N: MUC1 expression in intramucosal colorectal neoplasms. Possible involvement in histogenesis and progression. Oncology 56: 223-231, 1999.

This work is licensed under a Creative Commons Attribution-NonCommercial-NoDerivatives 4.0 International (CC BY-NC-ND 4.0) License. 